\title{
Delineation of flood plain extension
}

\author{
Farhad Sakhaee* ${ }^{\text {a }}$,Sahar Azimnezhad ${ }^{\text {b }}$ \\ ${ }^{\text {a }}$ School of Engineering, Parks College of Engineering, Aviation and Technology, \\ Saint Louis University, USA \\ ${ }^{\mathrm{b}}$ Tehran Municipality. Behesht St. Tehran, Iran.
}

Floodplain delineation is an effective approach in either avoiding of water crisis or making pragmatic decisions in terms of water management strategies. In this study a flood plain extension has been developed in ArcGIS and HE-CRAS models and a comparison has been made within three different scenarios of discharge. The results showed in low and medium discharge scenarios the buffer zone acts as a safety factor zone to adjacent infrastructure either agricultural or residential, but in high discharge condition buffer zone is entirely filled with stream water hence yet more safety regulation should be considered in order to avoid human and resource loss or damage within adjacent areas.

Keywords: Flood plain delineation, Water depth profile, HE-CRAS,

F. Sakhaee. Parks College of Engineering, Aviation and Technology, Civil Engineering Dept., Saint Louis University, USA

Corresponding author: Farhad Sakhaee +1 618-353-7104

S. Azimnezhad. Tehran Municipality. Behesht St. Tehran, Iran, Email address: Sahar.azimnezhad@gmail.com

\section{I.Introduction}

Flooding and similar water crisis are common threats to modern cities, hence our infrastructures should be design and operate in a dynamic mode which can easily handle and decrease the negative impact of such events. Floodplains however may happen in any geographical areas and at different locations along river corridors.[1]The remote sensing data has been used for floodplain mapping for tropical wetlands. Analysis of such images has been retrieved an effective algorithm to estimate the extension of flooded areas.[2] Hydrological processes which results in occurrence of flood in lowland river has been already investigated and the surprising result was the usage of buffer zones between farmlands and the riverine environment.[3]A Set of experimental investigations has been done in UK on water table fluctuations in floodplain of Severn, Hampshire in order to understand the interactions between the river, floodplain and the adjacent hillslope.[3]In this study floodplain extension of a riverbed which has path through different land usehas been investigated under three different discharge scenario in HEC-RAS to estimate the efficiency of buffer zone as well as flood extension within the river stream.

\section{Materials and Methods}

This study consists of four primary steps which are briefly explained below and demonstrated in details later. Firstly, the layers have been constructed in ArcGIS. Second part includes the creation of format of layers and load them from their original location in ArcGIS. Third phase includes the transformation of all created files in Arc GIS into HEC-RAS and run the 
program for different scenarios. Finally,the resultsof flood plain extension has been transferred into ArcGIS to visualize the outputs in the real bed stream domain which has been presented in results part.

\section{Part 1. Layer construction in ArcGIS}

Digital topography map (TOPO_DTM) of river stream has been converted into a shape file from a cad-file then has been used as a polyline layer in proceeding steps in ArcMap. (Figure 1.a)

To have a better sense of visualization main file with a $20 \%$ transparency has been added as a background layer which is helpful both in visually analysis of flow and flood plain delineation at the end. (Figure 1.b) Raster file which has been created from two previous figures presented in Figure 1.c. Four layers of stream, banks, flow, and cross sections have been developed within Arc catalog.

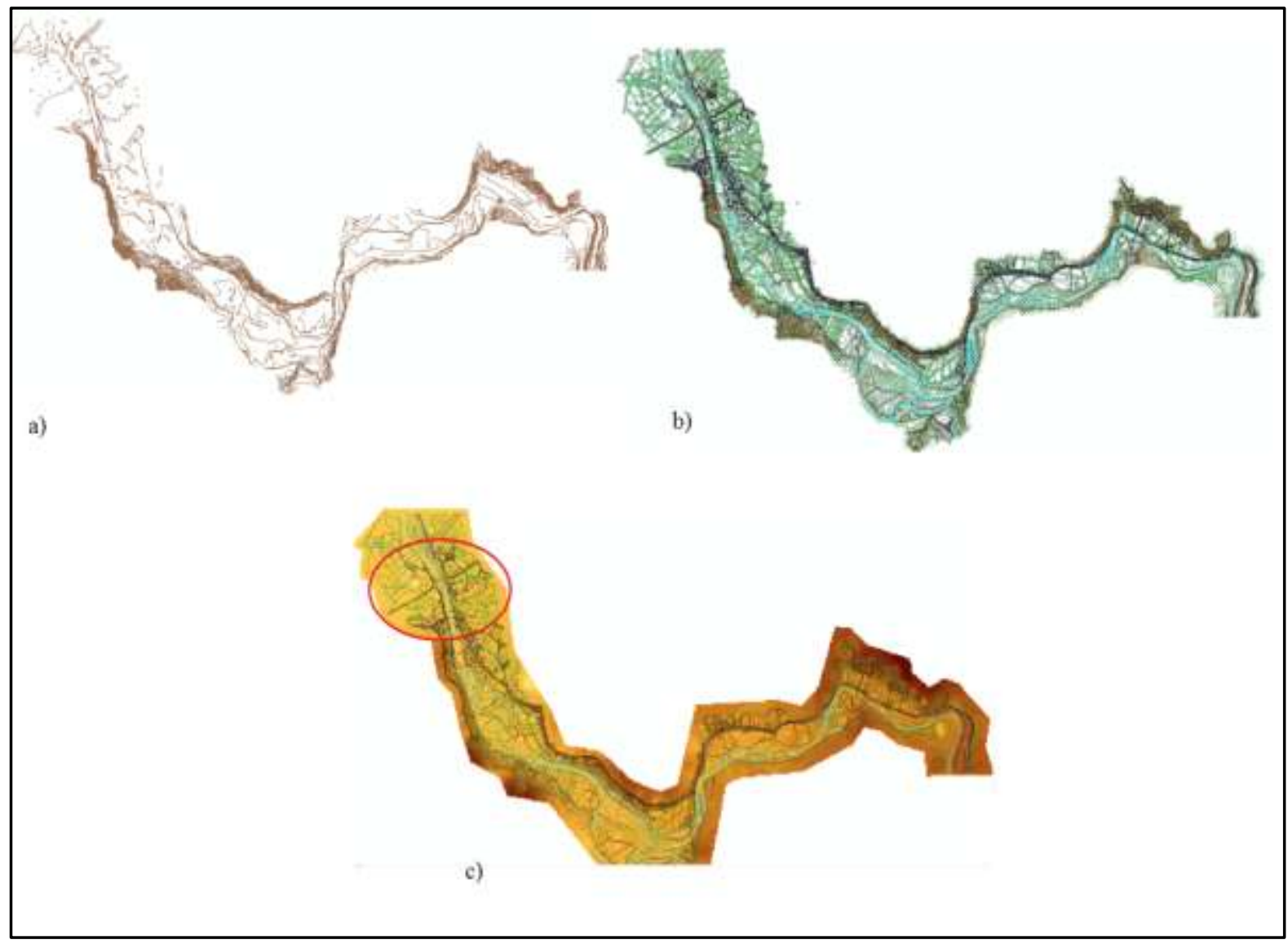

Figure 1:(a) Contour layers in polyline format, (b) TOPO_DTM layer, (c)Raster file created from river stream.

\section{Part 2. HEC-Geo-RAS}

In this part with the help of Ras Geometry, format of all previous layers have been created and they have been loaded from their original location in ArcGIS. Assigning different IDs to all created cross sections as well as land use for different sections of river extension and alos buffer zone of the river, all have been developed in this stage. In this study buffer zone considered to ba a 50 meters from the talweg point of the main stream. Landuse allocation has been presented in Table 1 below within three different zones including buffer, mountainous, and flat land. [4-8](See S.I.1) Different zones creation and alocation of Manning's coefficient presnted in figure 2. 
Table 1. Zoning areas.

\begin{tabular}{ccc}
\hline Zone & Land Use type & $\begin{array}{c}\text { Land Use Manning } \\
\text { coefficient }\end{array}$ \\
\hline$\underline{1}$ & Mountain & 0.06 \\
$\underline{2}$ & Plato (Flat Land) & 0.04 \\
$\underline{3}$ & Stream Buffer Zone & 0.035 \\
\hline
\end{tabular}

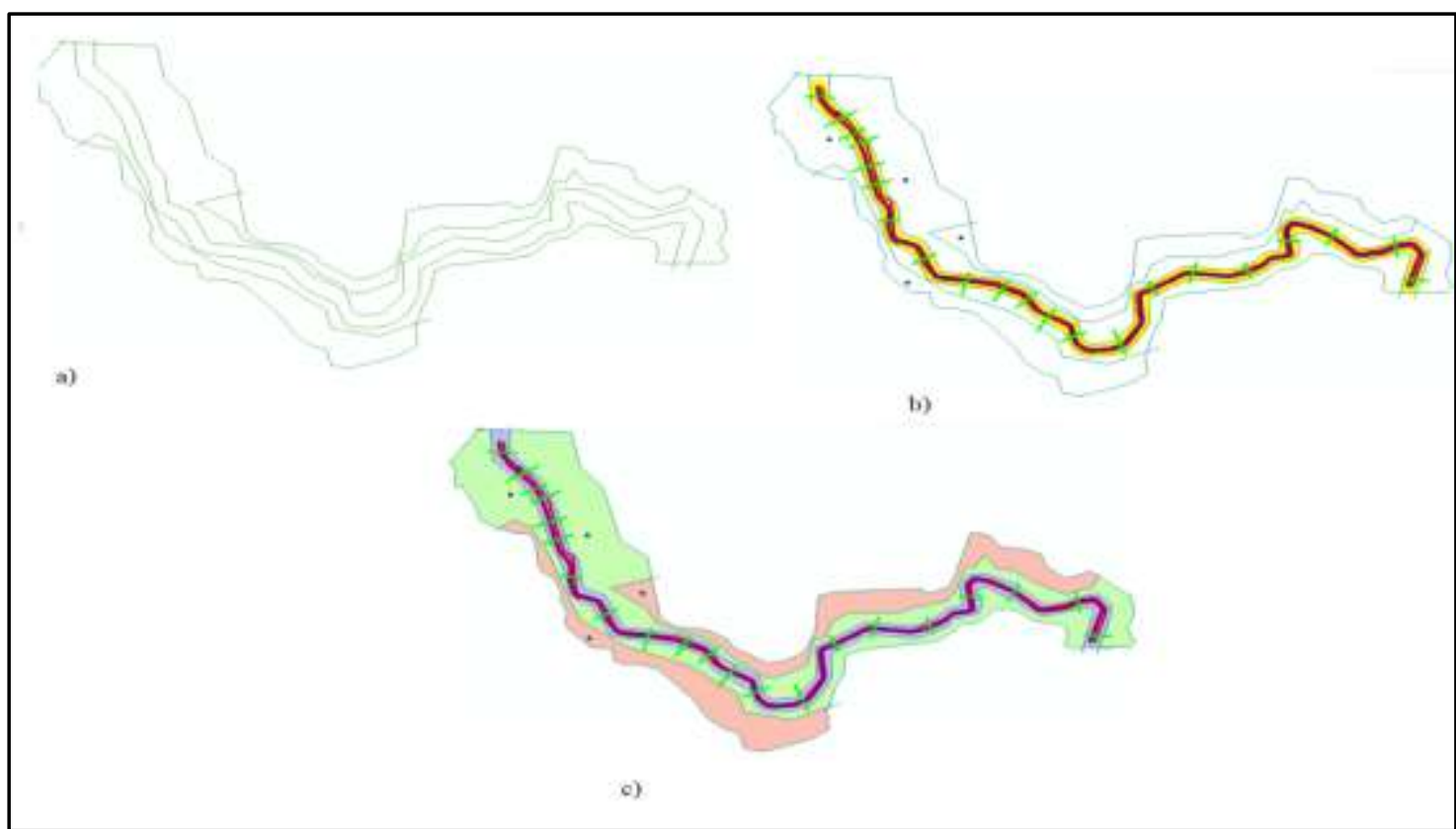

Figure 2:(a) Creating different zones, (b) Buffer zone construction,(c)Buffer,

Mountainous, and flat land zones allocation

Part 3. Bridge designin HECRAS

As it is shown if Figure 1.c inside the red circle there is a bridge section at the downstream of the river which has been designed in HEC-RAS bridge section and presented in figure 3 and figure 4 below. Bridge specification presented in Table 2. Below.

Design detail presented in Supplementary information section. (See S.I. 2a-e)

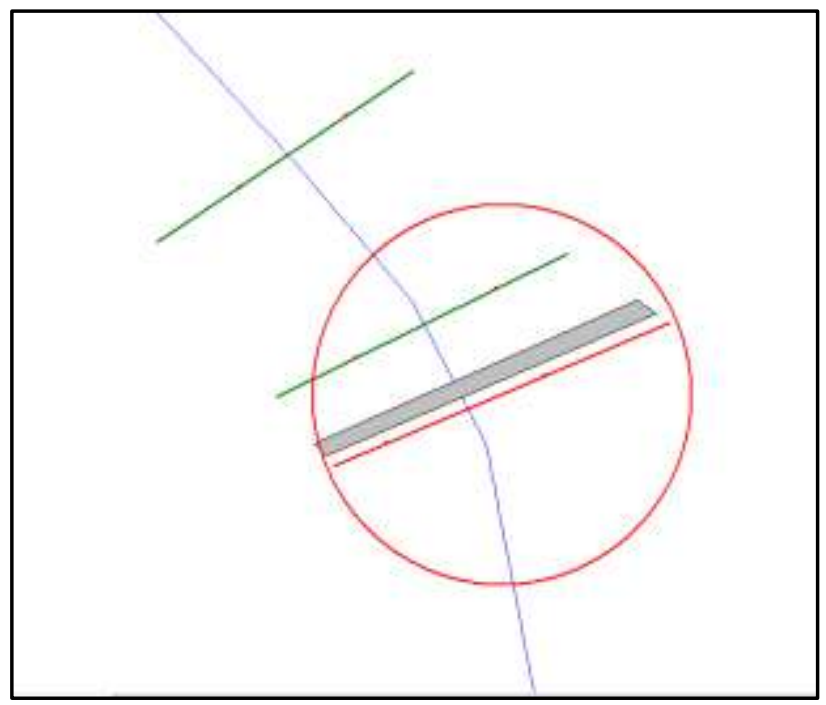

Figure 3. Bridge configuration. 
Table 2. Bridge Specifications

\begin{tabular}{|c|c|c|c|c|c|c|}
\hline $\begin{array}{c}\text { Width } \\
(\mathbf{m})\end{array}$ & $\begin{array}{c}\text { Dist. from } \\
\text { Upstream } \\
(\mathbf{m})\end{array}$ & $\begin{array}{c}\text { High chord } \\
\text { Elevation. } \\
(\mathbf{m})\end{array}$ & $\begin{array}{c}\text { Low chord } \\
\text { Elevation. } \\
(\mathbf{m})\end{array}$ & No. of Piers & $\begin{array}{c}\text { Upstream } \\
\text { XS starting } \\
\text { Station. }\end{array}$ & $\begin{array}{c}\text { Pier width } \\
(\mathbf{m})\end{array}$ \\
\hline 12 & 9 & 85 & 84 & 6 & 80 & 0.9 \\
\hline
\end{tabular}

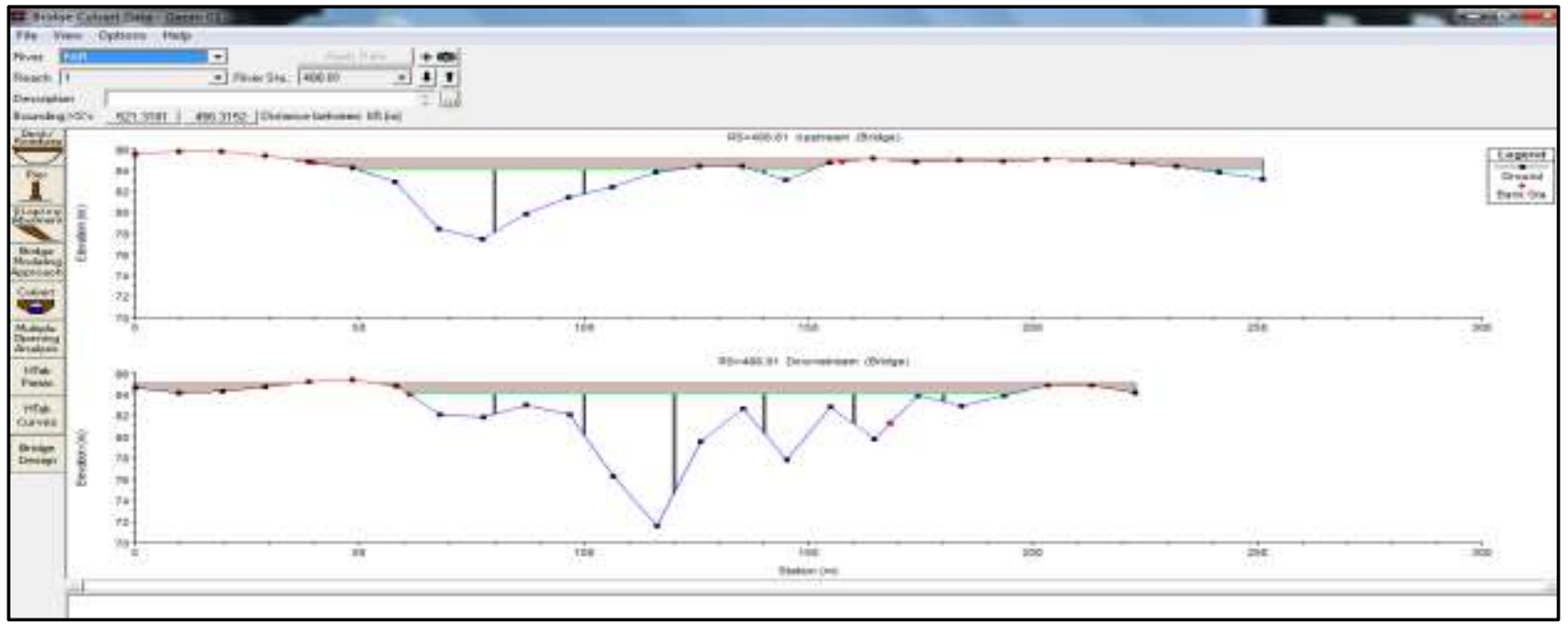

Figure 4. Bridge cross section.

\section{Results}

In this part, all the outcomes from HEC-RAShave been recalledback into ArcGIS to delineate the flood plain extension within three different scenarios of river discharges. Three different discharges from low to medium and high have been selected and water depth profile within the stream has been developed for each of them. In discharge of $Q=50 \mathrm{~m}^{3} / \mathrm{s}$, there is a small portion of boundary layer which has been sporadically filled with water and there is a lot of discontinuity within the water profile due to low discharge. (Figure 5.a) By increasing discharge to an average condition, $\mathrm{Q}=500 \mathrm{~m}^{3} / \mathrm{s}$, higher portion of boundary layer has been covered and water depth profile is deeper and more consistent.(Figure 5.b) In the maximum discharge scenario of $\mathrm{Q}=1000 \mathrm{~m}^{3} / \mathrm{s}$, whole extension of buffer zone has been filled with water.(Figure 5.c)

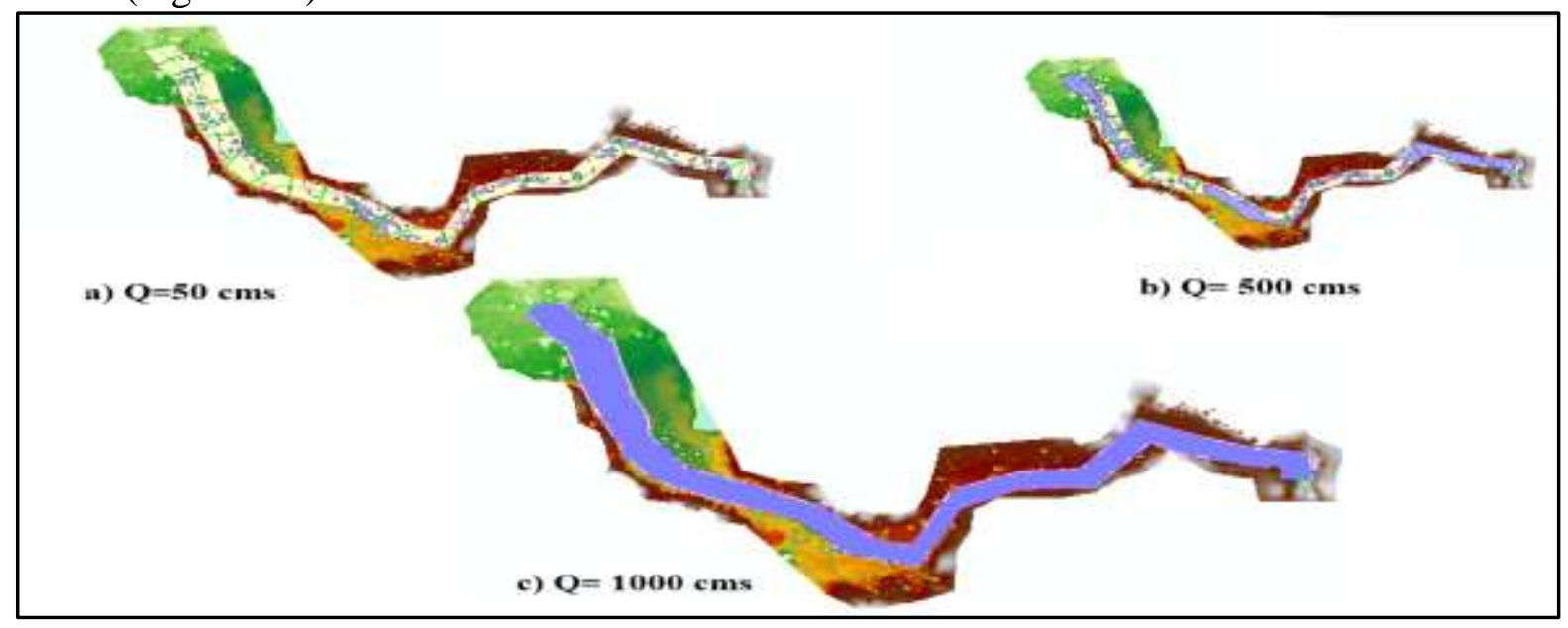

Figure 5. 2-D Configuration of the 


\section{Conclusion}

Flood plain delineation is important because it is a useful tool in estimating flood crisis either from extent or cost point of view. It can be also applied in determining erosion and sedimentation pattern of floodways, river streams and channels to calculate a regular dredging program $[8,9]$.Protection structure for river and channel are inevitable hence the use of development of flood maps for agricultural, industrial and residential areas adjacent to river buffer zones is needed. As it is obvious in figure 5. a by having low flow rate in seasonal streams there is no concern of flooding but as the flow rate increases the buffer zone would become active and becomes prone to sliding and erosion at the banks of the streams.

\section{References}

[1]. Tockner, K., F. Malard, and J. Ward, An extension of the flood pulse concept. Hydrological processes, 2000. 14(16-17): p. 2861-2883.

[2]. Martinez, J. Application of remote sensing data for the quantification of an Amazon floodplain extension, dynamics and river water storage. in Geophysical Research Abstracts. 2003.

[3]. Burt, T., et al., Water table fluctuations within the floodplain of the River Severn, England. Journal of Hydrology, 2002. 262(1-4): p. 1-20.

[4]. Coon, W.F., Estimates of roughness coefficients for selected natural stream channels with vegetated banks in New York. USGC water supply paper 2441, open file report 93-161, 1995.

[5]. Khatua, K., K. Patra, and P. Nayak, Meandering effect for evaluation of roughness coefficients in open channel flow. WIT Transactions on Ecology and the Environment, 2011. 146: p. 213-224.

[6]. Brevis, W., Y. Niño, and G. Jirka, Integrating cross-correlation and relaxation algorithms for particle tracking velocimetry. Experiments in Fluids, 2011. 50(1): p. 135-147.

[7]. Sakhaee, F., Bankfull discharge estimation for Fishpot Creek. Technium: Romanian Journal of Applied Sciences and Technology, 2020. 2(5): p. 74-91.

[8]. Sakhaee, F., Steady and unsteady flow simulation with SRH-2D. Journal of Ocean Engineering and Science, 2020.

[9]. Sakhaee, F. and F. Khalili, Sediment pattern \& rate of bathymetric changes due to construction of breakwater extension at Nowshahr port. Journal of Ocean Engineering and Science, 2020. 